\title{
KEDUDUKAN ANAK ANGKAT DALAM PEWARISAN MENURUT HUKUM ADAT BATAK TOBA DI DESA SIOGUNG-OGUNG KECAMATAN PANGURURAN KABUPATEN SAMOSIR
}

\section{Valentinus Rolando Naibaho' ${ }^{1}$, Mei Sinta Uli Br. Sihombing ${ }^{2}$}

${ }^{1}$ Fakultas Hukum, Universitas Prima Indonesia, email: valentinusnaibaho@gmail.com

\begin{abstract}
The traditional Batak Toba tribe adheres to the father's lineage system (patrilineal) so that the clan is arranged according to the father's lineage (patrilineal), in the Batak Toba community marriage is a living value to continue the offspring, therefore marriages that do not have children can do adoption. However, in its implementation there are still many conflicts and problems that occur in the position of adopted children in the Toba Batak customary tribe. Sources of data used in this paper are secondary collecting data that has been there before by collecting data contained in legislation relating to issues in this journal. According to the Batak Toba customary law adopted children have the same position as biological children, in Indonesia adoption must be carried out legally based on Indonesian Government Regulation No. 54 of 2007 concerning the implementation of adoption. The conclusion that we take is that the adopted child has the right to inheritance from his adoptive parents as long as the adopted child has followed all the processes in the Rajahon or inaugurated with a traditional ceremony.
\end{abstract}

\section{ARTICLE INFO}

Keywords:

Batak Toba; Inheritance;

Adopted children

\section{Cite this paper:}

Valentinus Ronaldo

Naibaho, M. S. (2021).

Kedudukan Anak Angkat

Dalam Pewarisan Menurut

Hukum Adat Batak Toba Di

Desa Siogung-Ogung

Kecamatan Pangururan

Kabupaten Samosir. Widya

Yuridika: Jurnal Hukum,

$4(2)$.

Scope Article

Law and Society

\section{PENDAHULUAN}

Indonesia memiliki bermacam ragam suku adat salah satunya ialah Suku adat Batak toba yang bermukim meliputi kabupaten toba samosir, Harahap mengatakan bahwasanya nenek moyang suku batak berasal dari utara yang pindah kekepulauan philipina setelah itu berpindah lagi ke Sulawesi selatan , mereka akhirnya berlayar kearah barat bersama dengan angin timur sampai ke sumatera selatan di sekitaran lampung setelah menjelajahi barat mereka mendarat di pelabuhan barus sekarang lalu pindah kepedalaman dan bermukim di kaki gunung pusuk buhit ditengah pulau samosir yang dianggap sebagai kawasan asal mula suku batak toba. ${ }^{1}$ Suku adat batak toba menganut system garis keturunan ayah (patrilineal) maka dengan begitu marga tersebut disusun menurut garis keturunan ayah ${ }^{2}$ karena

\footnotetext{
${ }^{1}$ Bungaran Antonius Simanjuntak, Konflik Status dan Kekuasaan Orang Batak Toba - Bagian Sejarah Batak, Yayasan Pustaka Obor Indonesia, Jakarta, 2009, hal 64.

2 Bungaran Antonius Simanjuntak, Arti dan Fungsi Tanah bagi Masyarakat Batak Toba, Karo, Simalungun, Yayasan Pustaka Obor Indonesia, Jakarta, 2015, hal 12.
} 
masyarakat batak toba menarik garis keturunan dari ayah maka posisi anak perempuan tidak sepadan dengan anak laki-laki dikarenakan derajat anak laki-laki lebih berpengaruh dibandingkan perempuan khususnya dalam hal warisan.

Pada masyarakat batak toba makna perkawinan ialah suatu nilai yang hidup untuk melanjutkan keturunan serta menjaga silsilah dalam keluarga. ${ }^{3}$ Dalam suatu perkawinan antara suami dan istri diharapkan akan mendapatkan keturunan yang baik dan merupakan sebuah tumpuan harapan bagi kedua orang tuanya. ${ }^{4}$ Oleh karena itu perkawinan yang tidak mempunyai keturunan dapat mengadakan pengangkatan seorang anak, pengangkatan anak ialah suatu cara mengangkat anak orang lain baik yang ada hubungan darah maupun tidak berhubungan darah. ${ }^{5}$ Akibat hukum dari pengangkatan anak adalah anak tersebut secara hukum memperoleh nama dari Bapak angkat, di jadikan sebagai anak yang berasal dari perkawinan orang tua angkat dan menjadi ahli waris orang tua angkat. ${ }^{6}$ Undang-undang nomor 23 tahun 2002 tentang perlindungan anak secara tegas menyatakan tujuan pengangkatan anak atau motivasinya hanya bisa dilaksanakan untuk menyediakan kebutuhan hidup dan menanggung hak-hak anak supaya dapat hidup, tumbuh, berkembang dan berpartisipasi secara maksimal serupa dengan harkat martabat kemanusiaan ${ }^{7}$

Namun dalam pelaksanannya sampai saat ini masih banyak terjadi konflik dan permasalahan yang terjadi dalam kedudukan seorang anak yang diangkat terutama dalam suku adat batak toba. Salah satunya ialah permasalahan tentang kedudukan anak angkat dalam pewarisan. Hukum waris merupakan hukum harta kekayaan dalam ruang lingkup dikarenakan seseorang wafat maka akan adanya pemindahan yang di tinggalkan oleh pewaris dapat berakibat bagi pemindahan ini untuk orang-orang yang mendapatkan warisan tersebut baik antara sesama ikatan keluarga mereka ataupun pihak ketiga. ${ }^{8}$

Dalam Hukum waris di Indonesia terbagi menjadi 3 sistem hukum, yaitu Hukum waris menurut Hukum Adat, Hukum waris menurut Hukum Islam, dan Hukum waris menurut BW (Burgelijk Wetboek) yang pemberlakuannya didasarkan pada pilihan hukum masyarakat. Pengaturan hukum waris menurut hukum adat mengacu pada system yang berlaku pada masing-masing masyarakat, pengaturan waris dalam Hukum Islam mengacu pada Kompilasi Hukum Islam yang mengatur tentang pembagian warisan menurut Kompilasi Hukum Islam (KHI), dan pengaturan waris menurut Hukum Perdata menuruti pengaturan dalam BW (Burgelijk Wetboek). ${ }^{9}$

Berlandaskan dari latar belakang tersebut, maka kami penulis sangat tertarik untuk mengangkat judul tentang Kedudukan Anak Angkat Dalam Pewarisan Menurut Adat Batak Toba Di Desa Siogung-Ogung Kabupaten Samosir.

Rumusan Masalah dalam penelitian ini yakni tentang Bagaimana kedudukan anak angkat dalam masyarakat batak toba di Desa SiOgung-Ogung Kabupaten Samosir, Bagaimana syarat-syarat pengangkatan anak dalam hukum adat batak toba di Desa SiOgung-

\footnotetext{
${ }^{3}$ Sri Hajati et.al, Buku Ajar Hukum Adat, Kencana, Jakarta, 2018, hal 208.

${ }^{4}$ Aladdin dan Agil, Tesis: "Perbandingan antara Kedudukan Anak Angkat dalam Hukum Waris Islam Berdasarkan Kompilasi Hukum Islam (KHI) dengan Kitab Undang-Undang Hukum Perdata (KUHPerdata)"(Semarang: Universitas Islam Sultan Agung, 2019), Hal 1.

5 Ibid, hal 1986

${ }^{6}$ Irma Devita Purnamasari, Hak Waris Anak Adopsi Menurut Hukum Barat dan Hukum Islam, Diambil dari: https://www.hukumonline.com/klinik/detail/ulasan/lt50877107ba949/hukum-waris-anak-adopsi/

${ }^{7}$ Undang-undang Nomor23 Tahun 2002 Tentang Perlindungan Anak

${ }^{8}$ Ronald Saijadan dan Roger F.X.V Letsoin, Buku Ajar Hukum Perdata, Deepublish, Yogyakarta, 2016, hal 107.

${ }^{9}$ Sintia Stela Karaluhe, Kedudukan Anak Angkat Dalam Mendapatkan Harta Warisan Ditinjau Dari Hukum Waris, Dimuat Dalam Jurnal, Volume 4, Nomor. 1.
} 
Ogung dan Bagaimana pembagian warisan anak angkat dalam suku batak toba di Desa SiOgung-Ogung Kabupaten Samosir.

Adapun Tujuan dari Penelitian ini yaitu guna mengetahui kedudukan anak angkat masyarakat batak toba di desa siogung-ogung, guna mengetahui syarat-syarat pengangkatan anak dalam hukum adat batak toba di desa siogung-ogung dan guna mengetahui pembagian warisan anak angkat dalam suku adat batak toba di desa siogung-ogung.

\section{METODE}

Jenis Penelitian ini menggunakan penelitian yuridis empiris, yaitu pendekatan dalam mencari dan mendapatkan data yang diperlukan, tidak hanya dalam segi-segi yuridis saja melainkan juga pada hasil penelitian dilapangan. Sifat Penelitian yang digunakan dalam penelitian ini menggunakan penelitian deskriptif yakni penelitian yang bersifat menggambarkan serta memaparkan masalah berkaitan dengan penelitian. Sumber bahan hukum yang digunakan adalah data sekunder yaitu mengumpulkan data yang telah ada sebelumnya (perpustakaan), dengan mengumpulkan data yang terdapat dalam peraturan perundang-undangan, buku-buku, serta tulisan yang berkaitan.

1. Bahan Hukum Primer meliputi:

- Kitab Undang-Undang Hukum Perdata (Burgelijk Wetboek)

- UU Nomor 4 Tahun Tahun 1979 tentang Kesejahteraan Anak

- Peraturan Pemerintah Nomor 54 Tahun 2007 Tentang Pengangkatan Anak

2. Bahan Hukum Sekunder

Yaitu memberikan penjelasan dari bahan hukum primer seperti uu, buku serta tulisan yang berkaitan dengan penelitian.

3. Bahan Hukum Tersier

Bahan yang memberi petunjuk dan penjelasan terhadap bahan hukum primer dan sekunder seperti internet, kamus hukum, dan kamus besar Bahasa batak toba.

Pengumpulan data yang di gunakan yakni dengan mempelajari buku-buku serta dokumen dan menganalisa bahan-bahan Pustaka yang berkatian dengan penelitian.

Analisis data yang di gunakan dalam penelitian ini yaitu analisis kualitatif dimana dengan menjawab dan memecahkan masalah dari pertanyaan-peranyaan yang bersumber dari buku, atau perundang-undangan serta wawancara.

\section{HASIL DAN PEMBAHASAN}

\section{Kedudukan anak angkat dalam masyarakat batak toba}

Anak angkat ialah suatu Tindakan hukum pada konteks hukum adat dan kekeluargaan(keturunan) jika seorang anak telah dikukut dipupon, diambil menjadi anak angkat, maka dia akan didudukan dan di terima dalam suatu posisi yang di persamakan baik biologis kendatipun sosial yang dahulu tidak melekat pada anak tersebut. ${ }^{10}$

Menurut Pendapat yang di kemukaakan oleh TerHaar, ia menyatakan bahwasannya seseorang anak yang telah diakui sebagai anak angkat, menciptakan hak-hak yuridis dan sosial baik di dalam persepektif hukum waris, keharusan nafkah dan perlindungan anak, perkawinann dan sosial kemasyarakatan. ${ }^{11}$

Adapun tujuan pengangkatan anak terdiri dari berbagai macam, yakni:

1. Hukum adat.

\footnotetext{
${ }^{10}$ Ahmad Kamil dan Fauzan, Hukum Perlindungan Dan Pengangkatan Anak Di Indonesia, Raja Grafindo Persada, Depok, 2017, hal 31.

11 Ibid.
} 
2. Hukum islam.

3. Perundang-undangan.

Pengangkatan anak berdasarkan hukum adat sangat bervariasi sementara itu pengangkatan anak berdasarkan hukum islam dan perundang-undangan mempunyai tujuan untuk kepentingan yang baik bagi anak. ${ }^{12}$ Dan menurut Pasal 2 Undang-Undang Nomor Tahun 1979 Tentang Kesejahteraan Anak yaitu :

1. Anak memiliki hak atas kepentingan, pemeliharaan, didikan dan pengarahan berdasarkan kasih sayang baik dalam keluarganya maupun didalam asuhan khusus untuk tumbuh dan berkembang dengan wajar.

2. Anak memiliki hak atas pelayanan dalam meluaskan kemampuan dan kehidupan sosialnya, serupa dengan kebudayaandankepribadian bangsa, dalam menjadi warga negara yang baik dan berguna.

3. Anak memiliki hak atas pemeliharaan dan perlindungan, baik semasa dalam kandungan maupun sesudah kelahiran.

4. Anak memiliki hak atas pertahanan tentang lingkungan hidup yang dapat membahayakannya atau menghambat pertumbuhan dan perkembangannya dengan wajar.

Pengangkatan anak juga bisa menjadi pancingan bagi suatu pasangan yang sudah sangat lama menantikan seorang anak agar dapat memiliki anak.

Menurut hukum adat batak toba anak angkat memiliki hak yang serupa dengan anak kandung, ${ }^{13}$ oleh karena itu pengangkatan anak secara hukum adat tidak mempunyai kekuatan hukum sebelum di resmikan sama pengadilan. Dikarenkan hal tersebut beberapa kasus perdata yang sifatnya sengketa (contentiosa) gugatan waris, yang umumnya terdapat petitum permohonan pengesahan pengangkatan anak yang telah berlangsung sangat lama dan dilaksanakan menurut hukum adat sekitar, demi untuk memperoleh harta warisan dari harta peninggalan orangtua angkatnya. ${ }^{14}$

\section{Syarat-syarat pengangkatan anak dalam hukum adat batak toba}

Pengangkatan anak menurut hukum adat adalah pengangkatan anak yang dilakukan menurut adat kebiasaan dalam satu lingkungan keluarga dan kerabat tertentu. ${ }^{15}$

Di Indonesia pengangkatan anak perlu dilaksanakan secara legal yang berdasarkan pada Peraturan Pemerintah Republik Indonesia no 54 tahun 2007 tentang pelaksanaan pengangkatan anak, dan berikut beberapa syarat-syarat pengangkatan anak di Indonesia, yakni syarat pengangkatan anak menurut hukum adat dan syarat pengangkatan anak menurut peraturan perundang-undangan.

1. Syarat pengangkatan anak menurut hukum adat batak toba

Menurut wawancara yang kami lakukan kepada pembicara adat (parhata adat) bapak juanda nababan syarat pengangkatan anak di dalam hukum adat adalah sebagai berikut:

A. Pasangan suami-istri yang ingin mengambil seorang anak menjadi anak angkat harus di pastikan terlebih dahulu tidak memiliki seorang anak laki-laki.

\footnotetext{
12 MusthofaSy, Pengangkatan Anak Kewenangan Pengadilan Agama, Kencana, Jakarta, 2008, hal 41.

13 Wawancara dengan Bapak Juanda Nababan di desa Si ogung-ogung Kabupaten Samosir Pada Tanggal 19

Februari 2021

${ }^{14}$ Ibid hlm 43

${ }^{15}$ Yayasan Sayap Ibu, Prosedur Pengangkatan Anak Domestik Oleh Warga Negara Indonesia, Diambil dari: http://sayapibujakarta.org/prosedur-pengangkatan-anak-domestik-oleh-warga-negara-indonesia/
} 
B. Anak yang ingin diangkat harus lah anak dari keluarga dekat seperti adik atau kakak kandung dari pasangan yang ingin mengangkat anak.

C. Pengangkatan anak harus dilakukan dengan cara di rajahon atau dilakukan dengan upacara adat batak yang akan di hadiri oleh hula-hula, dongan tubu, boru, serta pengetua-pengetua adat setempat.

Dikarenakan masih banyaknya di Indonesia pengangkatan anak berdasarkan kebiasaan adat setempat (Pasal 9 ayat 1 PP 54 Tahun 2007) dan pengangkatan secara adat kebiasaan di perbolehkan dan dilakukan dengan tata cara dan syarat-syarat sesuai di dalam masyarakat adat bersangkutan (Pasal 19 PP 54 Tahun 2007). ${ }^{16}$

2. Syarat pengangkatan anak menurut peraturan perundang-undangan di Indonesia.

Persyaratan pengangkatan anak Pasal 12 PP No. 54 Tahun 2007 tentang pelaksanaan pengangkatan anak sebagai berikut:

1. Syarat anak yang akan di angkat, yaitu:

a. Belum berusia 18(delapan belas) tahun;

b. Merupakan anak terlantar atau ditelantarkan;

c. Berada dalam asuhan keluarga atau dalam Lembaga pengasuhan anak;

d. Memerlukan perlindungan khusus.

2. Usia anak angkat sebagaimana dimaksud diatas meliputi:

a. Anak belum berusia 6(enam)tahun, merupakan prioritas utama;

b. Anak berusia 6(enam)tahun sampai dengan belum berusia 12(duabelas), sepanjang ada alasan mendesak;

c. Anak berusia 12(dua belas)tahun sampai dengan belum berusia 18(delapanbelas)tahun, sepanjang anak memerlukan perlindungan khusus.

\section{Bagaimana pembagian warisan anak angkat dalam suku batak toba}

Peraturan mengenai pembagian harta warisan di Indonesia terdapat 3 macam, yaitu menurut Hukum Islam, Hukum Perdata (BW) dan Hukum Adat:

Pembagian harta warisan anak angkat menurut Hukum Islam.

Kompilasi hukum islam (KHI) menunjuk pengertian anak angkat dalam pasal 171 huruf (h) sebagai : anak yang dalam pemeliharaan untuk hidupnya sehari-hari,biaya pendidikan dan sebagainya beralih dari orang tua asal kepada orang tua angkatnya berdasarkan putusan pengadilan. ${ }^{17}$ Di Dalam hukum islam pembagian harta warisan diberikan kepada keluarga wanita (anak-anak perempuan, cucu-cucu perempuan, ibu dan nenek pihak perempuan, saudara perempuan sebapak seibu, sebapak atau seibu saja). Ahli waris berjumlah 25 orang, yang terdiri dari 15 orang dari pihak laki-laki dan 10 orang dari pihak perempuan.

\footnotetext{
${ }^{16}$ Letezia Tobing, Keabsahan Pengangkatan Anak Secara Adat, Diambil dari: https://www.hukumonline.com/klinik/detail/ulasan/lt54622bbfeebc1/keabsahan-pengangkatan-anaksecara-adat/

${ }^{17}$ Drs. H.Nur Mujib, MH.,Anak Angkat Dan Sengketa Waris, Diambil dari: https://www.pajakartatimur.go.id/artikel/332-anak-angkat-dan-sengketa-

waris\#: :text=Karena\%20bukan\%20ahli\%20waris\%2C\%20maka, mendapatkan\%20harta\%20warisan\%20orangtua\% 20angkatnya.
} 
Adapun ahli waris dari pihak laki-laki sebagai berikut:

1. Anak laki-laki (al ibn)

2. Cucu laki-laki, yaitu anak laki-laki dan seterusnya kebawah (ibnul ibn)

3. Bapak (al ab)

4. Datuk, yaitu bapak dari bapak (al jad)

5. Saudara laki-laki seibu sebapak (al akh as syqiq)

6. Saudara laki-laki sebapak (al akh liab)

7. Saudara laki-laki seibu (al akh lium)

8. Keponakan laki-laki seibu sebapak (ibnul akh as syaqiq)

9. Keponakan laki-laki sebapak (ibnul akh liab)

10. Paman seibu sebapak

11. Paman sebapak (al ammu liab)

12. Sepupu laki-laki seibu sebapak (ibnul ammy as syaqiq)

13. Sepupu laki-laki sebapak (ibnul ammy liab)

14. Suami (az zauj)

15. Laki-laki yang memerdekakan, maksudnya orang yang memerdekakan seorang hamba apabila sihamba tidak mempunyai ahli waris.

Sedangkan ahli waris dari pihak perempuan adalah :

1. Anak perempuan (al bint)

2. Cucu perempuan (bintul ibn)

3. Ibu (al um)

4. Nenek, yaitu ibunya ibu (al jaddatun)

5. Nenek dari pihak bapak ( al jaddah minal ab)

6. Saudara perempuan seibu sebapak (al ukhtus syaqiq)

7. Saudara perempuan sebapak (al ukhtu liab)

8. Saudara perempuan seibu (al ukhtu lium)

9. Isteri (az zaujah)

10. Perempuan yang memerdekakan (al mu'tiqah)

Sebelum ahli waris menerima harta warisan, ada kewajiban ahli waris terhadap pewaris menurut ketentuan pasal $175 \mathrm{KHI}$ yaitu :

1. Mengurus dan menyelesaikan sampai pemakaman jenazah selesai

2. Menyelesaikan baik hutang-hutang berupa pengobatan, perawatan termasuk kewajiban pewaris maupun menagih piutang.

3. Menyelesaikan wasiat pewaris

4. Membagi harta warisan diantara ahli waris yang berhak ${ }^{18}$

Sedangkan pemberian harta warisan kepada anak angkat walaupun anak angkat tidak memiliki hubungan darah dengan orang tua angkatnya namun ia berhak mendapatkan perhatian, kasih sayang dari orang tua angkatnya sama seperti anak kandung, mendapatkan nafkah, mendapatkan Pendidikan yang layak dan hak untuk mendapatkan pemenuhan kebutuhan kehidupan. Oleh karena tidak adanya hubungan darah anak angkat terhadap orang tua angkatnya maka anak angkat tidak bisa menjadi ahli waris bagi harta warisan orang tua angkatnya sesuai dengan pasal 174 Kompilasi Hukum Islam. Walaupun anak angkat tersebut tidak menjadi ahli waris untuk harta orang tua angkatnya, anak angkat berhak atas bagian harta warisan orang tua angkatnya dengan mendapatkan bagian atas dasar wasiat wajibah sebagaiman diatur dalam pasal 209 ayat (2). ${ }^{19}$

\footnotetext{
${ }^{18}$ Sugali, Pembagian Harta Waris Menurut Hukum Islam dan KUH Perdata, Diambil dari: http://sugalilawyer.com/pembagian-harta-waris-menurut-hukum-islam-dan-kuh-perdata-bw/

${ }^{19}$ Zahra Ayu Agridiaryni, Hak Anak Angkat Terhadap Harta Warisan Menurut Huukum Waris Islam Di Indonesia, Diambil dari:
} 


\section{- Pembagian Harta Warisan Anak Angkat Menurut Hukum Perdata}

Waris menurut perdata adalah hukum waris berupa perangkat ketentuan hukum waris berupa perangkat ketentuan hukum yang terbantu diakibatkan hukum pada umumnya di bidang hukum yang terbantu akibat hukum pada ummumnya di bidang hukum harta kekayaan karena kematian seseorang yaitu pengalihan harta yang di tanggapi oleh akibatakibat pengasingan tersebut bagi para penerimanaya,baik dalam hubungan antar mereka maupun antar mereka dengan pihak ketiga. ${ }^{20}$ Waris juga merupakan salah satu cara yang limitative di peruntukan untuk memperoleh hak milik dan karena benda (hak) milik merupakan salah satu unsur pokok dalam sutau benda maka hukum waris diatur dalam buku II Bersama-sama dengan pengaturan benda yang lain,dalam pasal 584 KUHPerdata hak milik dari suatu benda tak dapat di peroleh dengan cara lain melainkan,pemilikan,karena perlekatan karena kadaluarsa,karena pewarisan baik menurut undang-undang maupun menurut surat wasiat, ${ }^{21}$ dalam hukum waris perdata ada beberapa pihak yang menjadi ahli waris secara alami yakni mereka yang di tunjuk sesuai undang-undang,anatara lain suami/istr,anak,kakek/nenek,dan alinnya sebagaimana termasuk dalam golongan IV.hak ini disebut dengan instestato.pihak yang di tunjuk secara khusussebagai ahli waris sesuai isi wasiat milik pewaris.umummnya disebut surat wasiat,surat ini tetap perlu disahkan oleh notaris.hak ini disebut dengan testamenter.anak yang masih berada di dalam kandungan.walau belum dilahirkan,statusnya bisa disahkan langsung sebagai ahli waris jika di perlukan.hak ini di perkuat oleh ketentuan pasal 2 KUHPerdata $^{22}$, hukum perdata waris juga mengatur tentang pembagian harta kepada seorang anak angkat Dalam perspektifnya Hukum perdata Waris anak angkat mendapatkan hibah wasiat sebagai mana diatur dalam pasal 957 KUHPerdata bahwa Hibah wasiat adalah suatu penetapan wasiat yang khusus dengan mana si yang mewariskan kepada seorang atau lebih memberikan beberapa barangbarangnya dari suatu jenis tertentu seperti misalnya segala barang-barang bergerak atau tidak bergerak atau memberikan hak pakai hasil atas merseluruh atau sebagian harta peninggalannya.

Tetapi dalam hal pemberian hibah perlu dan harus juga di perhatikan hak ahli waris sahnya yang diatur dalam pasal 972 KUHPerdata bahwa apabila warisan tidak seluruhnya atau Sebagian diterimanya, atau apabila warisan diterimanya dengan hak istimewa akan pendaftaran harta peninggalan, dan yang ini mencukupi guna memenuhi akan segala wasiat, maka hibah-hibah itu dalam keseimbangan dengan besarnya, harus dikurangi, kecuali yang mewariskan tentang hal ini, telah menetapkan ketentuan-ketentuan lain dalam surat wasiatnya. ${ }^{23}$

\section{- Pembagian Harta Warisan Anak Angkat Menurut Hukum Adat}

Hukum waris adat adalah tata cara pewarisan menurut hukum adat yang berlaku .hukum ini merupakan konsekuensi dari masih terpeliharanya hukum adat di Indonesia sebagai bagian dari kekayaan bangsa Indonesia,dapat dikatakan bahwa keragaman kehidupan masyarakat Indonesia berbanding lurus dengan hukum adatnya,tidak terkecuali dengan hukum waris angkat ${ }^{24}$ adapun Pembagian harta warisan kepada anak angkat bisa

http://hukum.studentjournal.ub.ac.id/index.php/hukum/article/view/1215\#: :text=Meskipun\%20anak\%20angkat \%20bukan\%20sebagai,harta\%20peninggalan\%20orang\%20tua\%20angkatnya.

${ }^{20}$ Shallman, Tata Cara Pembagian Warisan Menurut Kitab Undang-Undang Hukum Perdata, Diambil dari: Tata Cara Pembagian Waris Menurut Kitab Undang-Undang Hukum Perdata (KUHPer) - Shallman (shallmanalfarizy.com)

${ }^{21}$ Mui Sumut, Hukum Waris Perdata, Diambil dari: HUKUM WARIS PERDATA - MAJELIS ULAMA INDONESIA PROVINSI SUMATERA UTARA (muisumut.com)

22 IDN Times, Pembagian Harta Warisan Begini Ketentuannya Diambil dari: Pembagian Harta Warisan Menurut Hukum Perdata, Begini Ketentuannya (idntimes.com)

${ }^{23}$ Dhea Prayitno, Apakah Anak Angkat Berhak Jadi Ahli Waris, Diambil dari: https://smartlegal.id/hukumkeluarga/2019/02/18/apakah-anak-angkat-berhak-jadi-ahli-waris/

${ }^{24}$ Wahyu Kuncoro, Waris Permasalahan Dan Solusinya, Raih Asa Sukses, Jakarta, 2015, Hal 12. 
terjadi apabila pewaris sudah meninggal dunia dan anak angkat memiliki kedudukan yang sama dengan anak kandung. Oleh karena itu, berdasarkan hukum adat maka dalam memilih siapa yang akan menjadi ahli waris digunakan dua macam garis inti ,yaitu:

A. Garis inti keutamaan

B. Garis inti penggantian

Adapun golongan Garis inti keutamaan yaitu garis hukum yang memutuskan urutanurutan keutamaan di antara kelompok-kelompok dalam keluarga pewaris dengan pengertian bahwa kelompok yang satu lebih diprioritaskan dari pada kelompok yang lain. Dengan garis inti keutamaan tadi, maka orang-orang yang memiliki hubungan darah terbagi dalam kelompok-kelompok, seperti berikut:
A. Kelompok-kelompok keutumaan I : Keturunan pewaris.
B. Kelompok-kelompok keutamaan II : Orangtua pewaris.
C. Kelompok-kelompok keutamaan III : Saudara-saudara pewaris dan keturunanya
D. Kelompok-Kelompok keutamaan IV : Kakek dan nenek pewaris.
E. Dan seterusnya.

Garis inti penggantian yaitu garis hukum yang bermaksud untuk memutuskan siapa di antara orang-orang di dalam kelompok-kelompok keutamaan tertentu, hadir sebagai ahli waris. Yang bersungguh-sungguh untuk menjadi ahli waris adalah:
A. Orang yang tidak memiliki hubungan dengan pewaris.
B. Orang yang sudah tidak ada lagi pehubungannya dengan pewaris. ${ }^{25}$

Namun di dalam hal ini bagaimana kedudukan anak angkat dalam pembagian harta warisan dalam perspektif hukum adat yang khususnya untuk suku batak toba. Untuk keluarga yang mengangkat anak, kedudukan anak yang di angkat tersebut dalam hukum adat batak toba diatur seperti yang sudah penulis dapatkan dari hasil mewawancarai pemuka adat (parhata) yaitu Bapak Juanda Nababan yang menjelaskan sebagai berikut: "Anak angkat mempunyai hak atas warisan orang tua angkatnya atau menjadi ahli waris selama anak angkat tersebut menghilangkan perangainya sebagai orang asing di dalam keluarga tersebut, dan pembagian harta warisan anak angkat dalam suku batak toba sama haknya dengan anak kandung dikarenakan anak angkat tersebut sudah dirajahon (diresmikan dengan upacara adat bataktoba)". Tetapi didalam pembagian hartawarisan tersebut tidak diatur berapa besar hak anak angkat dan anak kandung, pembagian besar dan kecilnya harta warisan tersebut tergantung orang tua yang memberikan berapa besar harta warisan yang di terima oleh anak angkat maupun anak kandung.

\section{PENUTUP}

1. Menurut hukum adat suku batak toba kedudukan anak angkat mempunyai kedudukan yang sama dengan anak kandung, tetapi pengangkatan anak secara adat tidak mempunyai kekuatan hukum sebelum disahkan oleh pengadilan.

2. Pasangan yang ingin mengangkat anak harus memenuhi syarat sesuai peraturanperaturan dalam adat batak toba. Pasangan tersebut sudah lama tidak mempunyai anak, anak yang di angkat haruslah anak dari keluarga dekat dan harus di rajahon atau di lakukannya acara adat dengan dihadirkannya hula-hula, dongan tubu, boru serta pengetua-pengetua adat.

\footnotetext{
${ }^{25}$ Soerjono soekanto dan Soleman, Hukum Adat Indonesia, Raja Grafindo Persada, Jakarta, 2016, hal 261.
} 
3. Anak angkat berhak akan harta warisan dari orang tua angkatnya selama anak angkat tersebut sudah mengikuti segala proses dirajahon atau diresmikan dengan upacara adat dan anak tersebut sudah menghilangkan perangainya sebagai orang asing dalam keluarga tersebut. Pembagian harta warisan adalah hak orangtuanya untuk memberikan atau membagi seberapa besar untuk anak angkat dan seberapa besar untuk anak kandung.

\section{SARAN}

1. Bagi keluarga atau pasangan yang akan mengangkat anak dengan mengikuti tata cara yang di atur menurut adat istiadat harus juga untuk melakukan pengangkatan anak secara perdata untuk menghindari terjadinya kasus gugatan waris dikarenkan pengangkatan anak secara adat tidak memiliki kekuatan hukum.

2. Pasangan yang mengangkat anak diharapkan tidak melanggar atau melewatkan semua proses pengangkatan anak menurut adat batak toba dikarenakan semua proses dan tata cara pengangkatan anak tersebut harus lah dilaksanakan dan dijalankan.

Anak angkat maupun anak kandung tidak boleh meminta atau menentukan besaran warisan untuk dirinya, tetapi hak untuk memberikan besar atau kecilnya harta warisan bagi anak kandung dan anak angkat sepenuhnya merupakan hak orang tua mereka.

\section{DAFTAR PUSTAKA}

\section{Peraturan Perundang-undangan}

Kitab Undang-Undang Hukum Perdata (Burgelijk Wetboek)

Undang-Undang Nomor 23 Tahun 2002 Tentang Perlindungan Anak

Undang-Undang Nomor 4 Tahun 1979 Tentang Kesejahteraan Anak

\section{Buku}

Hajati, Sri et. al, (2018), Buku Ajar Hukum Adat, Jakarta: Kencana

Kamil Ahmad dan Fauzan, (2017), Hukum Perlindungan dan Pengangkatan Anak di Indonesia, Depok: RajaGrafindo Persada

Saija Ronald dan Roger, (2018), Buku Ajar Hukum Perdata, Yogyakarta: Deepublish

Simanjuntak, Bungaran Antonius, (2009), Konflik Status dan Kekuasaan Orang Batak TobaBagian Sejarah Batak, Jakarta: Yayasan Pustaka Obor Indonesia

Simanjuntak, Bungaran Antonius, (2015), Arti dan Fungsi Tanah bagi Masyarakat Batak Toba, Karo, Simalungun, Jakarta: Yayasan Pustaka Obor Indonesia

Soekanto Soerjono dan Soleman, (2016), Hukum Adat Indonesia, Jakarta: RajaGrafindo Persada

Sy, Musthofa, (2008), Pengangkatan Anak Kewenangan Pengadilan Agama, Jakarta: Kencana Wahyu Kuncoro, (2015), Waris Permasalahan Dan Solusinya, Jakarta, Raih Asa Sukses

\section{Jurnal}

Agridiaryni, Zahra Ayu, Hak Anak Angkat Terhadap Harta Warisan Menurut Huukum Waris Islam Di Indonesia, Diambil dari:

http://hukum.studentjournal.ub.ac.id/index.php/hukum/article/view/1215\#: :te 
$\underline{\mathrm{xt}=\text { Meskipun} \% 20 \text { anak\%20angkat } \% 20 \text { bukan\%20sebagai,harta\%20peninggalan } \%}$ 20orang\%20tua\%20angkatnya

Aladdin dan Agil, (2019), Tesis: Perbandingan Antara Kedudukan Anak Angkat dalam Hukum Waris Islam Berdasarkan Kompilasi Hukum Islam (KHI) dengan Kitab UndangUndang Hukum Perdata (KUHPerdata), Semarang: Universitas Islam Sultan Agung.

Karaluhe, Sintia Stela, (2016), Kedudukan Anak Angkat dalam mendapatkan Harta Warisan ditinjau dari Hukum Waris, Dimuat Dalam Jurnal, Volume 4, Nomor. 1

\section{Wawancara}

Bapak Juanda Nababan di Desa Si Ogung-Ogung Kabupaten Samosir Pada 19 Februari 2021

\section{Website}

Prayitno, Dhea Apakah Anak Angkat Berhak Jadi Ahli Waris, Diambil: Mei 11, 2021, Dari:https://smartlegal.id/hukum-keluarga/2019/02/18/apakah-anak-angkatberhak-jadi-ahli-waris/

Purnamasari, Irma Devita, Hak Waris Anak Adopsi Menurut Hukum Barat dan Hukum Islam, Diambil; Mei 11, 2021,Dari:

https://www.hukumonline.com/klinik/detail/ulasan/lt50877107ba949/hukumwaris-anak-adopsi/

Tobing, Letezia, Keabsahan Pengangkatan Anak Secara Adat, Diambil dari:

https://www.hukumonline.com/klinik/detail/ulasan/lt54622bbfeebc1/keabsaha n-pengangkatan-anak-secara-adat/

Sugali, Pembagian Harta Waris Menurut Hukum Islam dan KUH Perdata, Diambil dari: http://sugalilawyer.com/pembagian-harta-waris-menurut-hukum-islam-dan-kuhperdata-bw/

Yayasan Sayap Ibu, Prosedur Pengangkatan Anak Domestik Oleh Warga Negara Indonesia, Diambil dari:http://sayapibujakarta.org/prosedur-pengangkatan-anak-domestikoleh-warga-negara-indonesia/

Drs. H. Nur Mujib, MH.,Anak Angkat Dan Sengketa Waris, Diambil dari: https://www.pajakartatimur.go.id/artikel/332-anak-angkat-dan-sengketawaris\#: :text=Karena\%20bukan\%20ahli\%20waris\%2C\%20maka,mendapatkan \%20harta\%20warisan\%20orangtua\%20angkatnya.

Mui Sumut, Hukum Waris Perdata, Diambil dari: HUKUM WARIS PERDATA - MAJELIS ULAMA INDONESIA PROVINSI SUMATERA UTARA (muisumut.com)

Shallman, Tata Cara Pembagian Warisan Menurut Kitab Undang-Undang Hukum Perdata, Diambil dari: Tata Cara Pembagian Waris Menurut Kitab Undang-Undang Hukum Perdata (KUHPer) - Shallman (shallmanalfarizy.com)

IDN Times, Pembagian Harta Warisan Begini Ketentuannya Diambil dari: Pembagian Harta Warisan Menurut Hukum Perdata, Begini Ketentuannya (idntimes.com) 